\title{
Concentrations of Heavy Metals and Nitrates in Eggplant Grown with a Biostimulator
}

\author{
Joanna Majkowska-Gadomska*, Artur Dobrowolski, \\ Emilia Mikulewicz, Anna Francke \\ Department of Horticulture, University of Warmia and Mazury in Olsztyn \\ Poland
}

Received: 18 January 2016

Accepted: 7 March 2016

\begin{abstract}
A greenhouse experiment was conducted in 2011-12 to determine the effects of fertilization using an Asahi SL biostimulator on heavy metal concentrations in two cultivars of eggplants (Solanum melongena L.) grown in an unheated plastic tunnel in the garden of the Research and Experimental Station of the University of Warmia and Mazury in Olsztyn. Eggplants with their high nutritional and biological values plus popularity, eggplants are an important crop economically. However, due to their temperature requirements, eggplants are difficult to grow in regions with less favorable climatic conditions. Biostimulants and biopreparations are applied to protect plants against exogenous stressors, and to promote their healthy growth and development. Such protective treatments are increasingly applied in the cultivation of thermophilous vegetables in colder climates. The Asahi SL biostimulator supports the plant's natural defense mechanisms, thus alleviating the negative effects of adverse environmental conditions. Under optimal growing conditions the biostimulator helps crops reach their full genetic potential. The experimental materials comprised plants of two eggplant cultivars: Black Beauty and Violetta Lunga. Seedlings were grown in line with the generally observed standards for eggplant cultivation. The heavy metal content of plant material (in fruit) was determined. The concentrations of heavy metals and nitrates (V) in eggplants grown in an unheated plastic tunnel did not exceed the maximum permissible levels. The biostimulator exerted varied effects on the heavy metal and nitrate (V) contents of eggplants, and it increased the accumulation of mercury in the edible parts of eggplants. A significant increase in the concentrations of cadmium and nitrates (V) was noted in the cv. Black Beauty control eggplants.
\end{abstract}

Keywords: vegetables, cadmium, lead, mercury, nitrates

\section{Introduction}

The eggplant (Solanum melongena L.; common name aubergine) is grown for its edible fruit. Eggplants

*e-mail: majkowska-gadomska@uwm.edu.pl are appreciated for their taste, nutritional value, and health-promoting properties, which contribute to their popularity among both dieticians and consumers [1]. According to the Food and Agriculture Organization [2], global eggplant production reached 48 million tons in 2013. Fleshy eggplant fruits are a rich source of minerals, in particular potassium, calcium, and phosphorus, and 
they have a low sodium content, which makes them an important component of the human diet $[3,4]$. Due to unfavorable temperature and light conditions, eggplants are not grown in Poland - especially in the northeastern parts of the country. Thus, biostimulants such as the Asahi SL biostimulator can play an important role in eggplant cultivation. The biostimulator contains natural compounds found in plant cells that participate in physiological and biochemical processes in plants [5]. It protects crops against adverse environmental conditions, increases their stress tolerance, and stimulates their growth and development.

The objective of this study was to determine the effects of the biostimulator on the concentrations of heavy metals and nitrates (V) in the fruits of two eggplant cultivars (Violetta Lunga and Black Beauty), grown in an unheated plastic tunnel in northeastern Poland.

\section{Materials and Methods}

A two factorial experiment was conducted in 2011-12 in the garden of the Research and Experimental Station of the University of Warmia and Mazury in Olsztyn. Eggplants were grown in an unheated plastic tunnel in a randomized block design with three replications. The first experimental factor was eggplant cultivar (Black Beauty and Violetta Lunga) and the second experimental factor was the application of the biostimulator, which was sprayed onto the leaves of eggplants. Plants sprayed with water served as control.

Seedlings were grown in propagators, in line with the generally observed standards for eggplant cultivation. Each year, seedlings were planted in the ground in the middle of May, at $50 \times 50 \mathrm{~cm}$ spacing. The experimental unit of each replicate consisted of 12 plants. Starting on the third day after transplanting, at 10-day-intervals, eggplants were sprayed three times with the biostimulator at a concentration of $0.1 \%$. Control plants were sprayed with water.

The mineral composition of soil was determined in each year of the study. The average values for the entire experimental period were as follows $\left(\mathrm{mg} \mathrm{dm}^{-3}\right)$ : $\mathrm{N}_{-} \mathrm{NO}_{3}$ : 27, P: 235, K: 65, Ca: 1,260, Mg: 294, Cl: 12, pH in $\mathrm{H}_{2} \mathrm{O}$ : 7.45, salinity: $0.34 \mathrm{mg} \mathrm{dm}^{-3}$, and heavy metals $\mathrm{Cd}: 0.07$ and $\mathrm{Pb}: 0.15\left(\mathrm{mg} \cdot \mathrm{dm}^{-3}\right)$. Chemical analyses were performed in the Chemical and Agricultural Station in Olsztyn. Nitrogen was determined using the Kjeldahl method.

Analyses of soil composition was carried out with the standard methods acidity in water with the concentrations of phosphorus and potassium determined by the EgnerRiehm method, magnesium by the Schachtschabel method, and calcium by the universal method proposed by Nowosielski. Heavy metals content was determined by atomic absorption spectrometry (AAS). The soil in which eggplant seedlings were planted was found to be abundant in phosphorus and magnesium, and no supplemental fertilization with those elements was needed throughout the experiment. Due to the low nitrate nitrogen content of soil, nitrogen was applied at a single rate of $90 \mathrm{~kg} \cdot \mathrm{ha}^{-1}$ in the form of ammonium nitrate, before transplanting the seedlings in the middle of May.

The recommended cultivation practices for eggplants were carried out. The fruits were harvested at the stage of commercial maturity, from mid-July to the end of September. The fruits intended for chemical analyses were collected in the middle of the growing season (around 10 August). Plant material was collected from the marketable yield in each replication to obtain an average sample per treatment.

At the laboratory of the Department of Horticulture, University of Warmia and Mazury in Olsztyn, the edible parts of plants were assayed for:

- Dry matter by drying to constant weight at $105^{\circ} \mathrm{C}[\mathrm{PN}-$ 90/A-75101/03].

- Nitrates (V) using the colorimetric method with salicylic acid.

Averaged samples of the three fruits collected from the marketable yield in each treatment were comminuted, dried at $65^{\circ} \mathrm{C}$ to constant weight, and ground in an electric grinder.

In a certified laboratory of the Chemical and Agricultural Station in Olsztyn (accreditation certificate No. AB 277 issued by the Polish Center for Accreditation in Warsaw), the plant material was mineralized with concentrated sulfuric acid and assayed for $\mathrm{Cd}, \mathrm{Pb}$, and $\mathrm{Hg}$ using AAS:

The results of two years of research, given as the average of the two years, were processed statistically by analysis of variance (ANOVA). The significance of differences between means was estimated using Tukey's confidence intervals at $\alpha=0.05$.

\section{Results and Discussion}

Asahi SL contains natural compounds found in plant cells, which participate in physiological and biochemical processes in plants. The biostimulator enhances the resistance of plants to abiotic stresses such as low temperature, drought, excessive moisture, and salinity [5]. By activating specific metabolic pathways, plants can adapt to adverse growing conditions [6]. However, their defensive responses are usually insufficient to prevent yield and quality losses. Asahi SL supports natural processes of plant growth and development, and improves their energy efficiency [5]. The use of biostimulants is recommended when vegetables are grown in areas with less favorable climatic conditions, such as the region of Warmia where the climate is cooler and average daily air temperatures are lower than in other Polish regions, which considerably shortens the growing season [7]. The optimum temperature for growing eggplants is above $10^{\circ} \mathrm{C}$. Lower temperatures negatively affect plant development by reducing water and nutrient uptake, leading to growth inhibition and wilting [4]. Temperatures in northeastern Poland vary over space and time due to considerable differences between local habitats [8]. Average daily air temperatures during the 
Table 1 . Average daily air temperatures during the growing season of eggplants in 2011-12, based on data provided by the Olsztyn Hydrological and Meteorological Station.

\begin{tabular}{|c|c|c|c|c|}
\hline \multirow{2}{*}{ Months } & \multicolumn{3}{|c|}{ Average daily air temperatures $\left({ }^{\circ} \mathrm{C}\right)$} \\
\cline { 2 - 5 } & 2011 & 2012 & $\begin{array}{c}\text { Montly } \\
\text { average } \\
(2011-2012)\end{array}$ & $\begin{array}{c}\text { Long-term } \\
\text { average } \\
1981-2010\end{array}$ \\
\cline { 2 - 5 } May & 13.4 & 13.4 & 13.3 & 13.5 \\
\hline June & 17.1 & 15.0 & 16.1 & 16.1 \\
\hline July & 17.9 & 19.0 & 18.5 & 18.7 \\
\hline August & 17.6 & 17.7 & 17.6 & 17.9 \\
\hline September & 14.1 & 13.5 & 13.8 & 12.8 \\
\hline October & 8.3 & 7.4 & 7.9 & 8.0 \\
\hline
\end{tabular}

growing season of eggplants are shown in Table 1, based on data provided by the Hydrological and Meteorological Station in Olsztyn.

Throughout the experimental period, average daily air temperatures were higher than the long-term average of $1981-2010$ by $0.2^{\circ} \mathrm{C}$ in July, by $0.3^{\circ} \mathrm{C}$ in August, by $1.0^{\circ} \mathrm{C}$ in September, and by $0.1^{\circ} \mathrm{C}$ in October.

The dry matter content of fruits is presented in Table 2. A statistical analysis revealed that the cultivar $\mathrm{x}$ fertilizer interaction had a significant effect on the dry matter content in. As regards the interaction effect, the highest dry matter content was determined in cv. Black Beauty fertilized with Asahi SL and cv. Violetta Lunga from the control treatment.

Heavy metals present in the edible parts of plants pose a threat to human health, and their accumulation is largely determined by their concentrations in the environment [9]. The heavy metal content of vegetables varies depending on the metal-accumulating capacity of plants [10]. The fruits of the analyzed eggplant cultivars sprayed with the biostimulator contained various amounts of heavy metals (Table 2), but the noted differences were not statistically significant.

Heavy metals may cause acute or chronic poisoning. Many patients remain asymptomatic for a long time, but eventually heavy metals may lead to mutations in human and animal cells [11]. A significant correlation has been found between the concentrations of heavy metals in foods and cancer mortality rates [12]. In the present study, the heavy metal content of eggplant fruit remained within permissible limits in all treatments [13].

Eggplant cultivars had no significant effect on the accumulation of heavy metals in the fruit. In cv. Black Beauty, heavy metals content was as follows: $\mathrm{Cd}$ : $0.00119 \mathrm{mg} \cdot \mathrm{kg}^{-1} \mathrm{DM}, \mathrm{Pb}: 0.047 \mathrm{mg} \cdot \mathrm{kg}^{-1} \mathrm{DM}$, and $\mathrm{Hg}$ : $0.00105 \mathrm{mg} \cdot \mathrm{kg}^{-1} \mathrm{DM}$. In cv. Violetta Lunga the respective values were $0.00085 \mathrm{mg} \cdot \mathrm{kg}^{-1} \mathrm{DM}, 0.038 \mathrm{mg} \cdot \mathrm{kg}^{-1} \mathrm{DM}$, and $0.00112 \mathrm{mg} \cdot \mathrm{kg}^{-1} \mathrm{DM}$ (Table 2). Asahi SL had no significant influence on the accumulation of cadmium and lead in eggplant fruit, but it contributed to an increase in mercury content. An analysis of the interaction between the experimental factors revealed that in cv. Black Beauty $\mathrm{Cd}$ content reached $0.00158 \mathrm{mg} \cdot \mathrm{kg}^{-1} \mathrm{DM}$ in the control treatment and $0.00080 \mathrm{mg} \cdot \mathrm{kg}^{-1} \mathrm{DM}$ in the Asahi SL treatment, whereas the respective values for $\mathrm{Hg}$ content were 0.00095 and $0.00116 \mathrm{mg} \cdot \mathrm{kg}^{-1} \mathrm{DM}$. In Violetta Lunga, $\mathrm{Cd}$ and $\mathrm{Hg}$ content was $0.00082 \mathrm{mg} \cdot \mathrm{kg}^{-1} \mathrm{DM}$ and $0.00102 \mathrm{mg} \cdot \mathrm{kg}^{-1} \mathrm{DM}$, respectively, in the control treatment, and $0.00089 \mathrm{mg} \cdot \mathrm{kg}^{-1} \mathrm{DM}$ and $0.00122 \mathrm{mg} \cdot \mathrm{kg}^{-1}$ DM, respectively, in the Asahi SL treatment. The noted differences were statistically significant.

Nitrates (V), regarded as undesirable mineral compounds in fruits, determine their suitability for processing or fresh consumption. Maximum levels for

Table 2. The effect of cultivar and fertilization with Asahi SL on the concentrations of heavy metals $(\mathrm{Cd}, \mathrm{Pb}, \mathrm{Hg})$ in the dry matter of eggplant fruit (mean values for 2011-12).

\begin{tabular}{|c|c|c|c|c|c|c|}
\hline \multirow{2}{*}{ Cultivar } & \multirow{2}{*}{ Treatment } & \multirow{2}{*}{ Dry matter (\%) } & \multicolumn{3}{|c|}{ Heavy metals $\left(\mathrm{mg} \cdot \mathrm{kg}^{-1} \mathrm{DM}\right)$} & \multirow{2}{*}{$\begin{array}{c}\text { Nitrates } \\
\left(\mathrm{mg} \mathrm{NO}_{3}^{-1} \cdot \mathrm{kg}^{-1} \text { fresh weight }\right)\end{array}$} \\
\hline & & & $\mathrm{Cd}$ & $\mathrm{Pb}$ & $\mathrm{Hg}$ & \\
\hline \multirow{2}{*}{ Black Beauty } & Control & 8.76 & 0.00158 & 0.043 & 0.00095 & 323.3 \\
\hline & Asahi SL & 9.54 & 0.00080 & 0.050 & 0.00116 & 293.1 \\
\hline \multicolumn{2}{|c|}{ Mean values for cultivars } & 9.15 & 0.00119 & 0.047 & 0.00105 & 308.2 \\
\hline \multirow{2}{*}{ Violetta Lunga } & Control & 9.69 & 0.00082 & 0.032 & 0.00102 & 176.5 \\
\hline & Asahi SL & 8.49 & 0.00089 & 0.044 & 0.00122 & 217.8 \\
\hline \multicolumn{2}{|c|}{ Mean values for cultivars } & 9.09 & 0.00085 & 0.038 & 0.00112 & 197.2 \\
\hline \multirow{2}{*}{$\begin{array}{l}\text { Mean values for } \\
\text { treatments }\end{array}$} & Control & 9.23 & 0.00120 & 0.038 & 0.00098 & 249.9 \\
\hline & Asahi SL & 9,02 & 0.00084 & 0.047 & 0.00114 & 255.5 \\
\hline \multicolumn{7}{|c|}{$\mathrm{LSD}_{0.05}$} \\
\hline \multicolumn{2}{|c|}{ Cultivar (a) } & n.s. & n.s. & n.s. & n.s. & 27.1 \\
\hline \multicolumn{2}{|c|}{ Treatment (b) } & n.s. & n.s. & n.s. & 0.00012 & n.s. \\
\hline \multicolumn{2}{|c|}{ Interaction $(\mathrm{a} \times \mathrm{b})$} & 0.19 & 0.00019 & n.s. & 0.00019 & 3.1 \\
\hline
\end{tabular}


nitrates in eggplant fruit were not set by Commission Regulation (EU) No. 1258/2011 of 2 December 2011 [13]. Therefore, in this study nitrate concentrations in eggplants were compared with those determined in the edible parts of cucumbers, and they were found to be within permissible limits. The fruits of cv. Black Beauty contained significantly higher concentrations of nitrates (V) than the fruits of cv. Violetta Lunga (Table 1). Asahi SL had no impact on nitrate (V) accumulation in eggplants. The fruits of cv. Black Beauty in the control treatment had the highest nitrate (V) content, and the lowest nitrate (V) levels were noted in the fruits of cv. Violetta Lunga in the control treatment.

\section{Conclusions}

1. The concentrations of heavy metals and nitrates (V) in eggplants grown in an unheated plastic tunnel did not exceed the maximum permissible levels.

2. The biostimulator Asahi SL exerted varied effects on the heavy metal and nitrate (V) content of eggplants, and it increased the accumulation of mercury in the edible parts of eggplants.

3. A significant increase in the concentrations of cadmium and nitrates (V) was noted in control eggplants of $\mathrm{cv}$. Black Beauty.

\section{Acknowledgements}

Our study was financed as part of research project No. 20.610.017-300.

\section{References}

1. GOLCZ A., POLITYCKA B., MARKIEWICZ B. Content of macrocomponents in eggplant (Solanum melongena
L.) grown in re-used organic substrates. Rocz. AR Pozn. CCCLXX, Ogrodn. 39, 13, 2005 [in Polish].

2. www.faostat.fao.com (27.12.2015 r.)

3. MARKIEWICZ B., GOLCZ A., BOSIACKI M., KLEIBER $T$. Influence of nitrogen, phosphorus and potassium fertilization on the content of micronutrients in aubergine fruits ( $\mathrm{So}$ lanum malongena L.) growing in organic substrates. Nauka Przyr. Technol. 6 (3), 45, 2015 [in Polish].

4. MAJKOWSKA-GADOMSKA J., WIERZBICKA B. Effect of the biostimulator Asahi SL on the mineral content of eggplants (Solanum melongenum L.) grown in an unheated plastic tunnel. J. Elem. 18 (2), 269, 2013. DOI: 10.5601/ jelem.2013.18.2.06

5. URBANOWICZ J. Influence of biostimulant Asahi SL on phytotoxicity effect of metribuzin used in potato cultivation Biuletyn Instytutu Hodowli i Aklimatyzacji Roślin - BIP w Radzikowie. 109, 2012 [in Polish].

6. CZECZKO R., MIKOS-BIELAK M. Effects of Asahi biostimulator application in the cultivation of different vegetable species. Ann. UMCS, Sec. E. 59 (3), 1073, 2004.

7. OLBA-ZIECTY E., GRABOWSKI J., GRABOWSKA K. Comparison of selected weather conditions in two mazurian lakelandmesoregions. Acta Agroph. 9 (3), 699, 2007 [in Polish].

8. BANASZKIEWICZ B., GRABOWSKA K., SZWEJKOWSKI Z. Precipitation characteristics within the Warmia and Mazury province in 2000-2002. Acta Agroph. 3 (1), 5, 2004 [in Polish].

9. ŚMIECHOWSKA M., FLOREK A. Content of heavy metals in selected vegetables from conventional, organic and allotment cultivation. J. Res. Applic. Agric. Engin. 56 (4),152, 2011.

10. SZWALEC A., MUNDAŁA P. Contents of $\mathrm{Cd}, \mathrm{Pb}, \mathrm{Zn}$ And $\mathrm{Cu}$ in root vegetables cultivated in Krakow city allotment gardens. Ochr. Środ. i Zasob. Natur. 53, 31, 2012.

11. STANIAK S. Sources and levels of lead in food. Pol. J. Agr. 19, 36, 2014 [in Polish].

12. OCIEPA-KUBICKA M., OCIEPA E. Toxic Effects of Heavy Metals on Plants, Animals and Humans. Inżynieria i Ochrona Środowiska. 15 (2), 169, 2012 [in Polish].

13. Commission Regulation (EU) No 1258/2011 of 2 December 2011 amending Regulation (EC) No 1881/2006 as regards maximum levels for nitrates in foodstuffs. 